\title{
Life Satisfaction and Work-Related Satisfaction among Anesthesiologists in Poland
}

\author{
Ewelina Gaszynska, ${ }^{1}$ Michal Stankiewicz-Rudnicki, ${ }^{2}$ Franciszek Szatko, ${ }^{1}$ \\ Andrzej Wieczorek, ${ }^{2}$ and Tomasz Gaszynski ${ }^{3}$ \\ ${ }^{1}$ Department of Hygiene and Health Promotion, Medical University of Lodz, Poland \\ ${ }^{2}$ Department of Anesthesiology and Intensive Therapy, Medical University of Lodz, Poland \\ ${ }^{3}$ Department of Emergency Medicine and Disaster Medicine, Medical University of Lodz, Poland \\ Correspondence should be addressed to Tomasz Gaszynski; tomasz.gaszynski@umed.lodz.pl
}

Received 3 April 2014; Accepted 30 April 2014; Published 9 June 2014

Academic Editor: Ehab Farag

Copyright (C) 2014 Ewelina Gaszynska et al. This is an open access article distributed under the Creative Commons Attribution License, which permits unrestricted use, distribution, and reproduction in any medium, provided the original work is properly cited.

The aim of the study was to assess the level of life and job satisfaction of Polish anesthesiologists and to explore the impact of extrinsic-hygiene and intrinsic-motivating determinants. Materials and Methods. A cross-sectional questionnaire study was conducted among consultant anesthesiologists in Lodz region. The questionnaire concerned patient care, burden, income, personal rewards, professional relations, job satisfaction in general, and life satisfaction. Respondents were asked to rate their level of satisfaction for each item on a seven-point Likert scale (1: extremely dissatisfied; 7: extremely satisfied). Results. 86.03\% of anesthesiologists were satisfied with their economic status, $77.94 \%$ found their health status satisfactory, and $52.21 \%$ viewed their personal future optimistically. In general, $71.32 \%$ of anesthesiologists were satisfied with their current job situation. Among the less satisfying job aspects were work-related stress $(2.49 ; \mathrm{SD}=1.23)$, administrative burden $(2.85 ; \mathrm{SD}=1.47)$, workload (3.63; $\mathrm{SD}=1.56)$, and leisure time $(3.09 ; \mathrm{SD}=1.44)$. Conclusions. Considerable work-related stress leads to job dissatisfaction among anesthesiologists. There is an association between job satisfaction and health status, social life, and economic status. Working for long hours by anesthesiologists results in a high risk of burnout.

\section{Background}

Job satisfaction is defined as positive feelings of individuals towards their job. According to the Two-Factor Theory of job satisfaction laid out by Herzberg and colleagues, the factors influencing satisfaction levels can be divided into intrinsicmotivating factors (recognition, work tasks, and responsibility) and extrinsic-hygiene factors (job security, working conditions, and salary) [1]. The presence of intrinsic motivators increases satisfaction levels, whereas the lack of extrinsichygiene factors may cause dissatisfaction. These factors acting on one another have been shown to be an important modifier of the quality of medical care. Highly satisfied workers care about the quality of their work, are more productive, and feel responsible for the working environment. Staff satisfaction should be a strategic aim of any healthcare system as it facilitates its organization and contributes to cost reduction. Different studies reveal that doctors, anesthesiologists in particular, suffer from occupational stress and burnout [2].

Over the last years working conditions of anesthesiologists in Poland have changed considerably and new forms of employment have emerged. Due to limited healthcare funding, hospitals have faced meticulous financial scrutiny and pressure to generate profits. This entailed a necessity to reduce the costs associated with the services provided (using cheapest treatment options that are not equally effective as other available ones) along with the need to improve workforce productivity. Administrative workload has increased as well. The media-created image of doctors was instrumental in the deterioration of social recognition and respect for medical profession. Doctors have to deal with the threat of 
malpractice litigation more than ever. On the other hand, maximum working hours have been reduced and, as a result of the continuous educational obligation, employers are now required to grant paid time-off to employees for further education and professional skills development. At a time of healthcare reorganization in Poland all of the mentioned factors may influence job satisfaction. Research on job satisfaction of anaesthesia providers was carried out in many countries. In Poland still little is known about the work-related well-being of anesthesiologists and the factors that could improve their situation.

The aim of this study was to assess the level of life and job satisfaction of Polish senior specialist anesthesiologists and to explore the impact of extrinsic-hygiene and intrinsicmotivating determinants. A potential modification of these factors may lead to the improvement of anaesthesiologists' performance in the working environment.

\section{Materials and Methods}

The study was approved by the Medical University of Lodz Research Ethics Board (number RNN/134/13/KB Lodz, Poland). In January 2013 postal survey with a covering letter was sent to all senior specialist anesthesiologists working within Lodzkie Voivodeship. The participants' names came from the register of Voivodeship Consultant updated in the year 2012, which covers all anesthesiologists employed in the Voivodeship. A cross-sectional questionnaire study was conducted among 177 senior specialist anesthesiologists from 14 hospitals in the general area of Lodz. Participants were asked to complete a questionnaire, which was a modified version of the questionnaire introduced by Bovier et al. and was returned in a prepaid envelope by mail. It included questions about each single intrinsic and extrinsic item of job satisfaction: patient care, burden, income, personal rewards, professional relations, and job satisfaction in general $[3,4]$. Other variables that are known to influence job satisfaction level were also taken into account: sociodemographic dataage, gender, marital status, years since graduation, mean number of working hours a week, type of employment, and number of employers (number of employment places) - and life satisfaction-standard of living, health status, predictions for the future, and social and family life. Respondents were asked to rate their level of satisfaction with each item on a seven-point Likert scale (1: extremely dissatisfied; 7: extremely satisfied).

2.1. Statistical Analysis. Data were summarized using means and standard deviations and were presented as frequency counts and percentages. Pearson's $r$ correlation coefficients were computed between separate aspects of life and job satisfaction in general. Gender differences in job satisfaction and differences between burnout and satisfied groups were compared using the nonparametric, Mann-Whitney $U$ test. An explanatory factor analysis, principal component analysis with varimax rotation, was conducted in order to define meaningful constituents (dimensions) in terms of work satisfaction among anesthesiologists. Hence, a five-dimensional model was used: patient care (autonomy in treating patients; quality of care one can provide), burden (workload; time available for family, friends, or leisure; work-related stress; administrative burden), income-prestige (current income; social status and respect), personal rewards (intellectual stimulation; opportunity for continuing medical education; enjoyment of work), and professional relations (with peers, nurses, and other staff). Internal consistency (Cronbach's $\alpha$ ) of the analyzed subscales is as follows: patient care: $\alpha=0.78$, burden: $\alpha=0.70$, income-prestige: $\alpha=0.55$, personal rewards: $\alpha=0.81$, and professional relations: $\alpha=0.71$.

\section{Results}

The response rate was $76.84 \%$ (136/177); $47.79 \%$ (65) were men. Average age of the participants was 48.74 years $(\mathrm{SD}=$ 9.96; quartiles: 41, 49, and 56.50). Private hospitals were not main employers for any of the respondents. Half of the anesthesiologists were employed in one hospital, 27.94\% were employed in 2, and $22.06 \%$ were employed in 3 or more. Most anesthesiologists worked under a fixed-term or permanent employment contract and reconciled this with self-employment, that is, contract for services. On average 22.93 years ( $\mathrm{SD}=10.34$; quartiles: $15,23.5$, and 31 respondents graduated from medical school ago) passed since the respondents graduated from medical school.

3.1. Life Satisfaction. Most participants were content (extremely satisfied, satisfied, or rather satisfied) with different aspects of their life: economic status, health status, outlooks for the future, and social and family life-86.03\%, 77.94\%, $52.21 \%, 55.15 \%$, and $74.99 \%$, respectively.

3.1.1. Job Satisfaction in General. In general, $71.32 \%$ of anesthesiologists were satisfied with their current job situation; most, however, (62.65\%) used the term "rather satisfied." Respondents declaring general satisfaction with their job were significantly more content with its different aspects, patient care $(P<0.001)$, income-prestige $(P<0.001)$, personal rewards $(P<0.001)$, burden $(P=0.009)$, professional relations $(P=0.024)$, and life in general, than the dissatisfied ones (Table 1). Family life was the only aspect that these differences did not apply to. The satisfied participants rated their health and economic status significantly higher $(P<$ $0.001)$. They also viewed their future more optimistically $(P<$ $0.001)$ and were more satisfied with their social $(P=0.036)$ and family life $(P=0.007)$.

Table 2 presents statistics describing satisfaction with 13 different job aspects and current job situation. Anesthesiologists' contentment with different job aspects was diverse. Best results were obtained for professional relations with nurses and other staff $(5.40 ; \mathrm{SD}=0.98)$ and relations with other doctors (5.10; $\mathrm{SD}=1.23$ ) as well as enjoyment of work (5.21; $\mathrm{SD}=1.14)$. Among the less satisfying job aspects were factors connected with work-related stress (2.49; SD =1.23), administrative burden $(2.85 ; \mathrm{SD}=1.47)$, workload (3.63; SD $=1.56)$, and leisure time $(3.09 ; \mathrm{SD}=1.44)$. 
TABLE 1: Computed statistical parameters (mean, SD, and quartiles) for each averaged scoring referring to patient care, burden, incomeprestige, personal rewards, and professional relations and different aspects of life among surveyed anesthesiologists being generally satisfied versus dissatisfied $^{\mathrm{a}, \mathrm{b}, \mathrm{c}}$.

\begin{tabular}{|c|c|c|c|c|c|c|c|}
\hline \multirow[t]{2}{*}{$\begin{array}{l}\text { Investigated "dimensions" of } \\
\text { work satisfaction or aspect of life }\end{array}$} & \multicolumn{3}{|c|}{$\begin{array}{l}\text { Job satisfaction in general-declared } \\
\text { general satisfaction of work }\end{array}$} & \multicolumn{3}{|c|}{$\begin{array}{l}\text { Job satisfaction in general-declared } \\
\text { general dissatisfaction of work }\end{array}$} & \multirow[t]{2}{*}{$P$ value $^{\mathrm{c}}$} \\
\hline & Mean & $\mathrm{SD}$ & Quartiles & Mean & $\mathrm{SD}$ & Quartiles & \\
\hline Patient care & 4.78 & 1.10 & $\begin{array}{c}4 \\
5 ; \\
5.5\end{array}$ & 3.69 & 1.27 & $\begin{array}{c}2.5 ; \\
4 ; \\
5\end{array}$ & $P<0.001$ \\
\hline Burden & 3.17 & 1.05 & $\begin{array}{c}2.25 \\
3 \\
4\end{array}$ & 2.63 & 0.92 & $\begin{array}{c}2 \\
2.5 \\
3.25\end{array}$ & $P=0.009$ \\
\hline Income-prestige & 4.56 & 0.94 & $\begin{array}{c}4 \\
4.5 \\
5.5\end{array}$ & 3.69 & 1.12 & $\begin{array}{c}3 \\
3.5 \\
4.5\end{array}$ & $P<0.001$ \\
\hline Personal rewards & 4.83 & 0.98 & $\begin{array}{c}4.33 \\
5 ; \\
5.67\end{array}$ & 3.97 & 1.19 & $\begin{array}{c}3 \\
4 \\
5\end{array}$ & $P<0.001$ \\
\hline Professional relations & 5.40 & 0.82 & $\begin{array}{c}5 \\
5.5 \\
6\end{array}$ & 4.86 & 1.21 & $\begin{array}{l}4 \\
5 \\
6\end{array}$ & $P=0.024$ \\
\hline Material status & 5.48 & 0.86 & $\begin{array}{l}5 \\
6 \\
6\end{array}$ & 4.79 & 1.22 & $\begin{array}{l}4 \\
5 \\
6\end{array}$ & $P<0.001$ \\
\hline Health status & 5.41 & 0.94 & $\begin{array}{l}5 \\
5 ; \\
6\end{array}$ & 4.49 & 1.30 & $\begin{array}{l}4 \\
5 \\
5\end{array}$ & $P<0.001$ \\
\hline Predicted future & 4.77 & 1.04 & $\begin{array}{c}4 \\
5 \\
6\end{array}$ & 4.00 & 1.08 & $\begin{array}{l}4 \\
4 \\
5\end{array}$ & $P<0.001$ \\
\hline Social life & 4.60 & 1.46 & $\begin{array}{l}4 \\
5 \\
6\end{array}$ & 3.87 & 1.94 & $\begin{array}{l}2 ; \\
4 ; \\
5\end{array}$ & $P=0.036$ \\
\hline Family life & 5.34 & 1.40 & $\begin{array}{l}5 ; \\
6 ; \\
6\end{array}$ & 5.00 & 1.59 & $\begin{array}{l}4 \\
5 ; \\
6\end{array}$ & $\left(\mathrm{NS}^{\mathrm{d}}\right)$ \\
\hline
\end{tabular}

a: extremely dissatisfied; 2: dissatisfied; 3: rather dissatisfied; 4: neither dissatisfied nor satisfied; 5: rather satisfied; 6: satisfied; 7: extremely satisfied.

b"Satisfied anesthesiologists" indicated the score ranging from 5 to 7 ; "dissatisfied anesthesiologists" chose the score ranging from 1 to 4 . The Mann-Whitney $U$ test was carried out.

3.2. Patient Care. $61.8 \%$ of the examined anesthesiologists were satisfied with their autonomy in treating patients. $64.6 \%$ were satisfied with the quality of care they can provide. A significant relation was observed between the autonomy in patient treatment and satisfaction with the quality of provided care.

3.3. Burden. The lowest satisfaction scores were found for burden. Only $36 \%$ were satisfied with their workload while $54.41 \%$ were dissatisfied. $72.06 \%$ found the time they can devote to their friends and family or leisure activities insufficient. 77.32\% were dissatisfied with work-related stress (assessed as too high). 69.12\% were dissatisfied with administrative burden.

3.4. Income-Prestige. More than a half of participating anesthesiologists (55.3\%) expressed satisfaction with their current income. One in every two were satisfied with their social status and the respect they have.

3.5. Personal Benefits. Most anesthesiologists (80.34\%) declare they enjoy their work. Around a half believes that 
TABLE 2: (a) Computed statistical parameters (mean, SD, and quartiles) along with frequencies for job situation in general and patient care aspects among surveyed anesthesiologists. (b) Computed statistical parameters (mean, SD, and quartiles) along with frequencies for each scoring referring to income-prestige among surveyed anesthesiologists.

(a)

\begin{tabular}{|c|c|c|c|c|}
\hline \multirow{2}{*}{ Elements to be assessed } & \multicolumn{3}{|c|}{ Statistical parameters } & \multirow{2}{*}{$\begin{array}{l}\text { Computed frequencies for } \\
\text { each scoring }^{\mathrm{a}}\end{array}$} \\
\hline & Mean & $\mathrm{SD}$ & Quartiles & \\
\hline Job situation in general & 4.86 & 1.18 & $\begin{array}{c}4 \\
5 \\
6\end{array}$ & $\begin{array}{l}2 \text { persons }(1.47 \%) \\
3 \text { persons }(2.21 \%) \\
13 \text { persons }(9.56 \%) \\
21 \text { persons }(15.44 \%) \\
58 \text { persons }(42.65 \%) \\
33 \text { persons }(24.26 \%) \\
6 \text { persons }(4.41 \%) \\
\end{array}$ \\
\hline Patient care & 4.46 & 1.25 & & \\
\hline $\begin{array}{l}\text { Autonomy in treating } \\
\text { patients }\end{array}$ & 4.43 & 1.45 & $\begin{array}{c}3 ; \\
5 ; \\
5\end{array}$ & $\begin{array}{l}4 \text { persons }(2.94 \%) \\
11 \text { persons }(8.09 \%) \\
27 \text { persons }(19.85 \%) \\
10 \text { persons }(7.35 \%) \\
53 \text { persons }(38.97 \%) \\
26 \text { persons }(19.12 \%) \\
5 \text { persons }(3.68 \%) \\
\end{array}$ \\
\hline $\begin{array}{l}\text { Quality of care one can } \\
\text { provide }\end{array}$ & 4.50 & 1.31 & $\begin{array}{c}3 ; \\
5 ; \\
5\end{array}$ & $\begin{array}{l}2 \text { persons }(1.47 \%) \\
9 \text { persons }(6.62 \%) \\
27 \text { persons }(19.85 \%) \\
10 \text { persons }(7.35 \%) \\
58 \text { persons }(42.65 \%) \\
29 \text { persons }(21.32 \%) \\
1 \text { person }(0.74 \%)\end{array}$ \\
\hline Burden & 3.01 & 1.04 & & \\
\hline Workload & 3.63 & 1.56 & $\begin{array}{c}3 ; \\
3 ; \\
5\end{array}$ & $\begin{array}{l}13 \text { persons }(9.56 \%) \\
19 \text { persons }(13.97 \%) \\
42 \text { persons }(30.88 \%) \\
13 \text { persons }(9.56 \%) \\
33 \text { persons }(24.26 \%) \\
13 \text { persons }(9.56 \%) \\
3 \text { persons }(2.21 \%) \\
\end{array}$ \\
\hline $\begin{array}{l}\text { Time available for family, } \\
\text { friends, or leisure }\end{array}$ & 3.09 & 1.44 & $\begin{array}{l}2 \\
3 \\
4\end{array}$ & $\begin{array}{l}16 \text { persons }(11.76 \%) \\
35 \text { persons }(25.74 \%) \\
47 \text { persons }(34.56 \%) \\
6 \text { persons }(4.41 \%) \\
24 \text { persons }(17.65 \%) \\
7 \text { persons }(5.14 \%) \\
1 \text { person }(0.74 \%)\end{array}$ \\
\hline Work-related stress & 2.49 & 1.23 & $\begin{array}{l}1 ; \\
2 ; \\
3\end{array}$ & $\begin{array}{l}38 \text { persons }(27.94 \%) \\
31 \text { persons }(22.79 \%) \\
36 \text { persons }(26.47 \%) \\
26 \text { persons }(19.12 \%) \\
3 \text { persons }(2.21 \%) \\
2 \text { persons }(1.47 \%) \\
\text { None }(0.00 \%)\end{array}$ \\
\hline
\end{tabular}


(a) Continued.

\begin{tabular}{|c|c|c|c|c|}
\hline \multirow{2}{*}{ Elements to be assessed } & \multicolumn{3}{|c|}{ Statistical parameters } & \multirow{2}{*}{$\begin{array}{l}\text { Computed frequencies for } \\
\text { each scoring }^{\mathrm{a}}\end{array}$} \\
\hline & Mean & $\mathrm{SD}$ & Quartiles & \\
\hline Administrative burden & 2.85 & 1.47 & $\begin{array}{l}2 \\
3 ; \\
4\end{array}$ & $\begin{array}{l}27 \text { persons }(19.85 \%) \\
38 \text { persons }(27.94 \%) \\
29 \text { persons }(21.33 \%) \\
20 \text { persons }(14.71 \%) \\
15 \text { persons }(11.03 \%) \\
6 \text { persons }(4.41 \%) \\
1 \text { person }(0.74 \%)\end{array}$ \\
\hline
\end{tabular}

a 1: extremely dissatisfied; 2: dissatisfied; 3: rather dissatisfied; 4: neither dissatisfied nor satisfied; 5: rather satisfied; 6: satisfied; 7: extremely satisfied.

(b)

\begin{tabular}{|c|c|c|c|c|}
\hline \multirow{2}{*}{ Elements to be assessed } & \multicolumn{3}{|c|}{ Statistical parameters } & \multirow{2}{*}{$\begin{array}{l}\text { Computed frequencies for } \\
\text { each scoring }^{\mathrm{a}}\end{array}$} \\
\hline & Mean & $\mathrm{SD}$ & Quartiles & \\
\hline Income-prestige & 4.31 & 1.06 & & \\
\hline Current income & 4.20 & 1.38 & $\begin{array}{l}3 \\
5 \\
5\end{array}$ & $\begin{array}{l}5 \text { persons }(3.68 \%) \\
12 \text { persons }(8.82 \%) \\
30 \text { persons }(22.06 \%) \\
14 \text { persons }(10.29 \%) \\
55 \text { persons }(40.44 \%) \\
19 \text { persons }(13.97 \%) \\
1 \text { person }(0.74 \%)\end{array}$ \\
\hline Social status and respect & 4.43 & 1.18 & $\begin{array}{c}4 ; \\
4.5 \\
5\end{array}$ & $\begin{array}{l}\text { None }(0.00 \%) \\
7 \text { persons }(5.15 \%) \\
25 \text { persons }(18.38 \%) \\
36 \text { persons }(26.47 \%) \\
41 \text { persons }(30.15 \%) \\
25 \text { persons }(18.38 \%) \\
2 \text { persons }(1.47 \%) \\
\end{array}$ \\
\hline Personal rewards & 4.59 & 1.11 & & \\
\hline Intellectual stimulation & 4.25 & 1.37 & $\begin{array}{l}3 \\
4 \\
5\end{array}$ & $\begin{array}{l}3 \text { persons }(2.21 \%) \\
15 \text { persons }(11.03 \%) \\
20 \text { persons }(14.70 \%) \\
34 \text { persons }(25.00 \%) \\
37 \text { persons }(27.21 \%) \\
25 \text { persons }(18.38 \%) \\
2 \text { persons }(1.47 \%) \\
\end{array}$ \\
\hline $\begin{array}{l}\text { Opportunity for } \\
\text { continuing medical } \\
\text { education }\end{array}$ & 4.29 & 1.41 & $\begin{array}{l}3 \\
5 \\
5\end{array}$ & $\begin{array}{l}1 \text { person }(0.74 \%) \\
16 \text { persons }(11.76 \%) \\
30 \text { persons }(22.06 \%) \\
17 \text { persons }(12.50 \%) \\
42 \text { persons }(30.88 \%) \\
27 \text { persons }(19.85 \%) \\
3 \text { persons }(2.21 \%)\end{array}$ \\
\hline Enjoyment of work & 5.21 & 1.14 & $\begin{array}{l}5 \\
5 \\
6\end{array}$ & $\begin{array}{l}1 \text { person }(0.74 \%) \\
3 \text { persons }(2.21 \%) \\
7 \text { persons }(5.15 \%) \\
16 \text { persons }(11.76 \%) \\
48 \text { persons }(35.29 \%) \\
50 \text { persons }(36.76 \%) \\
11 \text { persons }(8.09 \%)\end{array}$ \\
\hline
\end{tabular}


(b) Continued.

\begin{tabular}{|c|c|c|c|c|}
\hline \multirow{2}{*}{ Elements to be assessed } & \multicolumn{3}{|c|}{ Statistical parameters } & \multirow{2}{*}{$\begin{array}{l}\text { Computed frequencies for } \\
\text { each scoring }^{\mathrm{a}}\end{array}$} \\
\hline & Mean & $\mathrm{SD}$ & Quartiles & \\
\hline Professional relations & 5.25 & 0.98 & & \\
\hline Relations with peers & 5.10 & 1.23 & $\begin{array}{l}5 \\
5 ; \\
6\end{array}$ & $\begin{array}{l}2 \text { persons }(1.47 \%) \\
5 \text { persons }(3.68 \%) \\
9 \text { persons }(6.61 \%) \\
13 \text { persons }(9.56 \%) \\
47 \text { persons }(34.56 \%) \\
53 \text { persons }(38.97 \%) \\
7 \text { persons }(5.15 \%)\end{array}$ \\
\hline $\begin{array}{l}\text { Relations with nurses and } \\
\text { other staff }\end{array}$ & 5.40 & 0.98 & $\begin{array}{l}5 \\
6 \\
6\end{array}$ & $\begin{array}{l}1 \text { person }(0.74 \%) \\
\text { None }(0.00 \%) \\
5 \text { persons }(3.68 \%) \\
13 \text { persons }(9.56 \%) \\
46 \text { persons }(33.82 \%) \\
61 \text { persons }(44.85 \%) \\
10 \text { persons }(7.35 \%)\end{array}$ \\
\hline
\end{tabular}

a 1: extremely dissatisfied; 2: dissatisfied; 3: rather dissatisfied; 4: neither dissatisfied nor satisfied; 5: rather satisfied; 6: satisfied; 7: extremely satisfied.

the prospects for further education and professional development are good. $47.06 \%$ were satisfied with intellectual stimulation they gain at work.

3.6. Professional Relations. $78.78 \%$ were satisfied with the relations with their peers and $86.02 \%$ with the relations with nurses and other staff.

3.7. Relation to Sociodemographics and Life Satisfaction. Job satisfaction in general had strongest correlation with health status and predicted future followed by social life and economic status. Statistically significant $(P<0.001)$ correlation was found between satisfaction with social life $(r=0.40)$, health status $(r=0.30)$, and burnout, with time available for friends and family being the most important factor. Outlooks for the future (predicted future) were significantly $(P<0.001)$ influenced by health status, income, intellectual stimulation at work, and work enjoyment.

In our analysis, working hours were associated with the perceived burden level. Burnout level was significantly higher in anesthesiologists who worked more than 60 hours a week (Table 3). They assessed their health status and social and family life $(P \leq 0.05)$ as significantly worse than the physicians who work shorter (Table 4 ). Those working more than 20 years gave a less favourable assessment of their career outlooks (predicted future) and family and social life $(P \leq$ $0.05)$.

No statistically significant differences were found between men and women in the examined group. Different aspects of job satisfaction were also not influenced by marital status, place of residence, years since graduation, and number of jobs (employment places).

\section{Discussion}

The overall job satisfaction level among anesthesiologists in our study is comparable to the findings of other studies in different countries and is estimated at around 71-75\% [57]. Our results demonstrate that anesthesiologists working longer hours are more prone to burnout and are more likely to be dissatisfied with different aspects of life (except family life). This trend is progressive with age.

Some studies point to more demanding family life responsibilities and discrimination in the work environment as causes for a lower satisfaction level and greater workrelated stress issues among women. Others, including ours, cannot confirm these findings on the basis of observed survey results $[8,9]$. No differences in any of the examined aspects of job satisfaction between participants with various length of service have been recorded, which were observed elsewhere in Europe $[5,10,11]$.

The main positive determinants of job satisfaction among Polish anesthesiologists, similar to their Finnish and Swiss counterparts, were the quality of care one can provide and autonomy in patient treatment $[5,11]$. Most anesthesiologists are content with their income levels. This is, however, at the expense of long working hours, often exceeding the EU norms. According to a report by the Ministry of Health, based on questionnaires obtained from 384 hospitals, the average monthly gross income of a senior specialist anesthetist in mid-2008 was 7211 PLN. Basic salary usually constitutes a half of the total income, the rest being earnings for staying on duty. Self-employed doctors earn up to $300 \%$ more. They often stay on duty eight days a month, with record breakers even as many as 20 . This is where the earnings of more than 15000 PLN, declared by half of them, come from. More than $83 \%$ of doctors work longer than allowed by 
TABLE 3: Sociodemographic discrete predictors (along with corresponding $P$ values) of each scoring referring to job satisfaction in general, patient care, burden, income-prestige, personal rewards, and professional relations among surveyed anesthesiologists.

\begin{tabular}{|c|c|c|c|c|c|c|}
\hline \multirow{2}{*}{$\begin{array}{l}\text { Sociodemographic } \\
\text { variables/predictors }\end{array}$} & \multicolumn{6}{|c|}{ Surveyed "dimensions" of work satisfaction } \\
\hline & $\begin{array}{l}\text { Job satisfaction } \\
\text { in general }\end{array}$ & Patient care & Burden & Income-prestige & Personal rewards & $\begin{array}{l}\text { Professional } \\
\text { relations }\end{array}$ \\
\hline Gender & $\left(\mathrm{NS}^{\mathrm{b}}\right)$ & $\left(N S^{b}\right)$ & $\left(N S^{b}\right)$ & $\left(N S^{b}\right)$ & $\left(N S^{b}\right)$ & $\left(N S^{b}\right)$ \\
\hline (i) Male & 4.89 & 4.44 & 3.11 & 4.20 & 4.56 & 5.25 \\
\hline (ii) Female & 4.83 & 4.49 & 2.93 & 4.42 & 4.61 & 5.24 \\
\hline Marital status & $\left(\mathrm{NS}^{\mathrm{b}}\right)$ & $\left(N S^{b}\right)$ & $\left(N S^{b}\right)$ & $\left(N S^{b}\right)$ & $\left(\mathrm{NS}^{\mathrm{b}}\right)$ & $\left(N S^{b}\right)$ \\
\hline (i) Single & 4.89 & 4.51 & 2.89 & 4.19 & 4.44 & 5.29 \\
\hline (ii) Married & 4.85 & 4.45 & 3.06 & 4.36 & 4.64 & 5.23 \\
\hline Place of living & $\left(N S^{b}\right)$ & $\left(N S^{b}\right)$ & $\left(N S^{b}\right)$ & $\left(\mathrm{NS}^{\mathrm{b}}\right)$ & $\left(\mathrm{NS}^{\mathrm{b}}\right)$ & $\left(N S^{b}\right)$ \\
\hline (i) Big city (>20 000 citizens) & 4.84 & 4.38 & 2.94 & 4.13 & 4.48 & 5.18 \\
\hline (ii) Small town (<20 000 citizens) & 4.80 & 4.64 & 3.11 & 4.43 & 4.73 & 5.23 \\
\hline (iii) Rural area & 5.20 & 4.13 & 2.95 & 4.60 & 4.44 & 5.60 \\
\hline Years since graduation & $\left(N S^{b}\right)$ & $\left(\mathrm{NS}^{\mathrm{b}}\right)$ & $\left(N S^{b}\right)$ & $\left(\mathrm{NS}^{\mathrm{b}}\right)$ & $\left(\mathrm{NS}^{\mathrm{b}}\right)$ & $\left(\mathrm{NS}^{\mathrm{b}}\right)$ \\
\hline (i) $\leq 10$ & 5.31 & 4.90 & 3.44 & 4.37 & 5.09 & 5.63 \\
\hline (ii) $11-20$ & 5.04 & 4.24 & 3.14 & 4.37 & 4.39 & 5.39 \\
\hline (iii) $21-30$ & 4.57 & 4.23 & 2.69 & 4.05 & 4.47 & 4.90 \\
\hline (iv) $>30$ & 4.83 & 4.64 & 3.08 & 4.61 & 4.51 & 5.36 \\
\hline Working hours & $\left(N S^{b}\right)$ & $\left(N S^{b}\right)$ & $(P<0.001)$ & $\left(N S^{b}\right)$ & $\left(\mathrm{NS}^{\mathrm{b}}\right)$ & $\left(N S^{b}\right)$ \\
\hline (i) $\leq 60$ & 4.95 & 4.54 & 3.30 & 4.39 & 4.63 & 5.31 \\
\hline (ii) $>60$ & 4.73 & 4.37 & 2.61 & 4.20 & 4.52 & 5.16 \\
\hline Number of employment places & $\left(\mathrm{NS}^{\mathrm{b}}\right)$ & $\left(N S^{b}\right)$ & $\left(N S^{b}\right)$ & $\left(N S^{b}\right)$ & $\left(\mathrm{NS}^{\mathrm{b}}\right)$ & $\left(N S^{b}\right)$ \\
\hline (i) One & 4.85 & 4.49 & 3.11 & 4.29 & 4.50 & 5.13 \\
\hline (ii) Two or more & 4.87 & 4.44 & 2.92 & 4.34 & 4.67 & 5.37 \\
\hline
\end{tabular}

${ }^{a}$ One-way ANOVA or test for trend across ordered groups has been carried out when appropriate.

${ }^{\mathrm{b}} \mathrm{NS}$ : (statistically) not significant.

the EU standards [12]. One in ten doctors works continuously for more than 13 hours a day (also on weekends) and one in twenty even as long as 18 hours. Often doctors work continuously for more than 30 hours (staying on duty for 24 hours and then the standard 8-hour working day), especially in smaller, understaffed hospitals [13]. Anesthesiologists usually earn more but work longer as well. In 2011 the basic salary among senior anesthesiologists, without any extra income for staying on duty, was between 2499 PLN and 11500 PLN, median: 4080 PLN (83\% of respondents). Self-employed anesthesiologists earned between $26 \mathrm{PLN} / \mathrm{h}$ and $120 \mathrm{PLN} / \mathrm{h}$ in public hospitals, median: $67 \mathrm{PLN} / \mathrm{h}$, and between $45 \mathrm{PLN} / \mathrm{h}$ and $200 \mathrm{PLN} / \mathrm{h}$ in private hospitals, median: $94,5 \mathrm{PLN} / \mathrm{h}$. Anesthesiologists who completed the questionnaire in the ministry's study declared they had to work continuously for 24 hours 6 times a month on average; their mean working time was 267 hours a month, which is in line with the data on anesthesiologists' working time we obtained in our study [14].

Anesthesiologists are exposed to greater levels of stress than normative groups and as a result more frequently engage in alcohol and drug abuse, suffer from mental disorders, and find it more difficult to reconcile work with family life [15-18].

In Poland and Germany anesthesiologists experience more stress and are at a greater risk of burnout than general practitioners $[3,19]$. Stress is caused by the responsibility for providing safe and high quality medical services, dealing with challenging medical situations, and making ethically and therapeutically difficult decisions, which anesthesiologists face every day. Working in the operating theatre, the ICU, making preoperative assessment, treating chronic and acute pain, or working in an emergency department anesthesiologists provide services for as many as $50-60 \%$ of hospitalized patients $[20,21]$. That is why the proportion of the amount of workload, both with patients and with administrative burden, to leisure time remains unsatisfactory. Although data differs by country, it is estimated that as many as $25 \%$ of anesthesiologists are in the burnout high risk group [11, 2224]. Authors of the study conducted among perioperative clinicians in the United States reported higher burnout scores in physicians than nurse anesthetists and the highest ones among residents [9]. Young anesthesiologists during their training are more prone to burnout and depression compared to people of similar age but different specialization. Surveys conducted in Turkey and the United States also revealed that anesthesiologists, especially without support from the family, are more likely to report suicidal thoughts $[18,25]$.

Good peer relations have been proven to reduce probability of burnout. Although most participants of our study described their relations with other medical staff as positive, 
TABLE 4: Sociodemographic discrete predictors (along with corresponding $P$ values) of analyzed aspects of life in surveyed anesthesiologists.

\begin{tabular}{|c|c|c|c|c|c|}
\hline \multirow{2}{*}{$\begin{array}{l}\text { Sociodemographic } \\
\text { variables/predictors }^{\text {a }}\end{array}$} & \multicolumn{5}{|c|}{ Aspects of life } \\
\hline & Material status & Health status & Predicted future & Social life & Family life \\
\hline Gender & $\left(N S^{b}\right)$ & $\left(N S^{b}\right)$ & $\left(\mathrm{NS}^{\mathrm{b}}\right)$ & $\left(N S^{b}\right)$ & $\left(\mathrm{NS}^{\mathrm{b}}\right)$ \\
\hline (i) Male & 5.25 & 5.32 & 4.66 & 4.66 & 5.45 \\
\hline (ii) Female & 5.32 & 5.07 & 4.45 & 4.14 & 5.06 \\
\hline Marital status & $\left(N S^{b}\right)$ & $\left(N S^{b}\right)$ & $\left(N S^{b}\right)$ & $\left(\mathrm{NS}^{\mathrm{b}}\right)$ & $(P=0.001)$ \\
\hline (i) Single & 5.20 & 5.14 & 4.51 & 4.43 & 4.57 \\
\hline (ii) Married & 5.32 & 5.15 & 4.56 & 4.45 & 5.48 \\
\hline Place of living & $\left(N S^{b}\right)$ & $\left(N S^{b}\right)$ & $\left(N S^{b}\right)$ & $\left(N S^{b}\right)$ & $\left(N S^{b}\right)$ \\
\hline (i) Big city (>20 000 citizens) & 5.13 & 5.15 & 4.58 & 4.42 & 5.10 \\
\hline (ii) Small town ( $<20000$ citizens) & 5.32 & 5.20 & 4.58 & 4.36 & 5.44 \\
\hline (iii) Rural area & 5.80 & 4.93 & 4.33 & 4.40 & 5.07 \\
\hline Years since graduation & $\left(N S^{b}\right)$ & $(P=0.011)$ & $(P<0.001)$ & $(P=0.002)$ & $(P=0.028)$ \\
\hline (i) $\leq 10$ & 5.46 & 5.69 & 5.31 & 5.38 & 5.77 \\
\hline (ii) $11-20$ & 5.39 & 5.30 & 4.70 & 4.48 & 5.61 \\
\hline (iii) $21-30$ & 5.12 & 4.80 & 4.24 & 4.02 & 4.80 \\
\hline (iv) $>30$ & 5.33 & 4.76 & 4.36 & 4.14 & 5.25 \\
\hline Working hours & $\left(N S^{b}\right)$ & $(P=0.025)$ & $\left(N S^{b}\right)$ & $(P=0.008)$ & $(P=0.015)$ \\
\hline (i) $\leq 60$ & 5.39 & 5.31 & 4.60 & 4.74 & 5.50 \\
\hline (ii) $>60$ & 5.14 & 4.91 & 4.48 & 3.89 & 4.88 \\
\hline Number of employment places & $\left(N S^{b}\right)$ & $\left(\mathrm{NS}^{\mathrm{b}}\right)$ & $\left(\mathrm{NS}^{\mathrm{b}}\right)$ & $\left(\mathrm{NS}^{\mathrm{b}}\right)$ & $\left(\mathrm{NS}^{\mathrm{b}}\right)$ \\
\hline (i) One & 5.28 & 5.06 & 4.43 & 4.40 & 5.38 \\
\hline (ii) Two or more & 5.29 & 5.24 & 4.68 & 4.38 & 5.10 \\
\hline
\end{tabular}

${ }^{a}$ One-way ANOVA or test for trend across ordered groups has been carried out when appropriate.

${ }^{\mathrm{b}} \mathrm{NS}$ : (statistically) not significant.

anesthesiologists often have to deal with a lack of positive feedback from patients and colleagues. This can be attributed to the fact that anesthesiologists in the operating theatre are often perceived as mere comfort providers for surgeons, rather than critical elements of the process they are in practice.

Anesthesiologists evaluated their overall situation at work more favourably than primary care physicians (4.72) in Poland. Participants of our study, however, viewed their social status as lower and believed they received less respect from other people than general practitioners. Indeed, research carried out among patients and their relatives in Polish hospitals reveals that more than $2 / 3$ of patients do not know what the work of an anesthesiologist involves and that anesthesiologists are doctors [26]. Despite the threat of stress and burnout most anesthesiologists are more satisfied with their jobs than GPs.

High job satisfaction levels among doctors reduce their susceptibility to burnout and mental disorders. Dissatisfied medical staff are more prone to burnout which decreases patient safety. A satisfied doctor is more committed to work and more willing to make sacrifices, exhibits greater productivity levels and lowers labor costs, contributes to patient satisfaction, and is a prerequisite for a good work environment [27].

\section{Conclusions}

(1) Job dissatisfaction among anesthesiologists is caused by heavy stress exposure. Work enjoyment is a protective factor against dissatisfaction.

(2) Anesthesiologists are at a high risk for burnout, especially when working long hours.

(3) The situation of anesthesiologists in Poland could be improved by enforcing shorter working hours and lower stress exposure through the introduction of standards for medical practice.

\section{Conflict of Interests}

The authors declare that they have no conflict of interests.

\section{Authors' Contribution}

Ewelina Gaszynska designed the study, performed analysis and interpretation of data, and performed the statistical analysis; Tomasz Gaszynski collected data, participated in design of study, and helped to draft the paper; Franciszek Szatko conceived of the study, participated in its design and coordination, and helped to draft the paper; Michal 
Stankiewicz-Rudnicki translated the paper into English; all authors have given final approval to the version to be published.

\section{Acknowledgment}

The authors thank Mrs. Corrine Fidric for language correction of paper.

\section{References}

[1] F. Herzberg, B. Mausner, and B. B. Snydermann, The Motivation to Work, Jon Wiley \& Sons, New York, NY, USA, 2nd edition, 1967.

[2] P. Rama-Maceiras, S. Parente, and P. Kranke, "Job satisfaction, stress and burnout in anaesthesia: relevant topics for anaesthesiologists and healthcare managers?" European Journal of Anaesthesiology, vol. 29, no. 7, pp. 311-319, 2012.

[3] P. A. Bovier and T. V. Perneger, "Predictors of work satisfaction among physicians," European Journal of Public Health, vol. 13, no. 4, pp. 299-305, 2003.

[4] K. Lewtak, A. Poznańska, and M. J. Wysocki, "Predictors of work satisfaction among primary care physicians," Problemy Higieny i Epidemiologii, vol. 93, no. 3, pp. 558-567, 2012.

[5] P. M. Lindfors, O. A. Meretoja, S. M. Töyry, R. A. Luukkonen, M. J. Elovainio, and T. J. Leino, "Job satisfaction, work ability and life satisfaction among Finnish anaesthesiologists," Acta Anaesthesiologica Scandinavica, vol. 51, no. 7, pp. 815-822, 2007.

[6] K. Jenkins and D. Wong, "A survey of professional satisfaction among Canadian anesthesiologists," Canadian Journal of Anesthesia, vol. 48, no. 7, pp. 637-645, 2001.

[7] A. S. Nyssen, I. Hansez, P. Baele, M. Lamy, and V. De Keyser, "Occupational stress and burnout in anaesthesia," British Journal of Anaesthesia, vol. 90, no. 3, pp. 333-337, 2003.

[8] M. T. Kluger, K. Townend, and T. Laidlaw, "Job satisfaction, stress and burnout in Australian specialist anaesthetists," Anaesthesia, vol. 58, no. 4, pp. 339-345, 2003.

[9] S. A. Hyman, D. R. Michaels, J. M. Berry, J. S. Schildcrout, N. D. Mercaldo, and M. B. Weinger, "Risk of burnout in perioperative clinicians: a survey study and literature review," Anesthesiology, vol. 114, no. 1, pp. 194-204, 2011.

[10] B. Chiron, E. Michinov, E. Olivier-Chiron, M. Laffon, and E. Rusch, "Job satisfaction, life satisfaction and burnout in french anaesthetists," Journal of Health Psychology, vol. 15, no. 6, pp. 948-958, 2010.

[11] J. F. Kinzl, H. Knotzer, C. Traweger, W. Lederer, T. Heidegger, and A. Benzer, "Influence of working conditions on job satisfaction in anaesthetists," British Journal of Anaesthesia, vol. 94, no. 2, pp. 211-215, 2005.

[12] http://www.konsylium.pl/.

[13] Stańczyk: Pokaż, lekarzu, ile masz na koncie Wprost 2009:37, 1390, http://www.wprost.pl/ar/170999/Pokaz-lekarzuile-masz-na-koncie/Mirosław/.

[14] http://www.polanest.webd.pl/.

[15] C. L. Cooper, S. Clarke, and A. M. Rowbottom, "Occupational stress, job satisfaction and well-being in anaesthetists," Stress Medicine, vol. 15, pp. 115-126, 1999.

[16] P. M. Lindfors, K. E. Nurmi, O. A. Meretoja et al., "On-call stress among finnish anaesthetists," Anaesthesia, vol. 61, no. 9, pp. 856866, 2006.
[17] S. Luck and J. Hedrick, "The alarming trend of substance abuse in anesthesia providers," Journal of Perianesthesia Nursing, vol. 19, no. 5, pp. 308-311, 2004.

[18] Y. C. Abut, D. Kitapcioglu, K. Erkalp et al., "Job burnout in 159 anesthesiology trainees," Saudi Journal of Anaesthesia, vol. 6, no. 1, pp. 46-51, 2012.

[19] W. Heinke, P. Dunkel, E. Brähler, M. Nübling, S. Riedel-Heller, and U. X. Kaisers, "Burnout in anesthesiology and intensive care. Is there a problem in Germany?” Anaesthesist, vol. 60, no. 12, pp. 1109-1118, 2011.

[20] F. Clergue, "Time to consider nonphysician anaesthesia providers in Europe?" European Journal of Anaesthesiology, vol. 27, no. 9, pp. 761-762, 2010.

[21] E. De Robertis, P. Tomins, and H. Knape, "Anaesthesiologists in emergency medicine: the desirable manpower," European Journal of Anaesthesiology, vol. 27, no. 3, pp. 223-225, 2010.

[22] A. Morais, P. Maia, A. Azevedo, C. Amaral, and J. Tavares, "Stress and burnout among Portuguese anaesthesiologists," European Journal of Anaesthesiology, vol. 23, no. 5, pp. 433-439, 2006.

[23] W. Lederer, J. F. Kinzl, E. Trefalt, C. Traweger, and A. Benzer, "Significance of working conditions on burnout in anesthetists," Acta Anaesthesiologica Scandinavica, vol. 50, no. 1, pp. 58-63, 2006.

[24] G. S. De Oliveira Jr., S. Ahmad, M. C. Stock et al., "High incidence of burnout in academic chairpersons of anesthesiology: should we be taking better care of our leaders," Anesthesiology, vol. 114, no. 1, pp. 181-193, 2011.

[25] G. S. De Oliveira Jr., R. Chang, P. C. Fitzgerald et al., "The prevalence of burnout and depression and their association with adherence to safety and practice standards: a survey of united states anesthesiology trainees," Anesthesia and Analgesia, vol. 117, no. 1, pp. 182-193, 2013.

[26] A. Pytliński, "The anaesthesiologist in the patients 'and their relatives' opinion," AnestezjologIa I RatownIctwo, vol. 1, pp. 20 27, 2007.

[27] S. G. Benson and S. P. Dundis, "Understanding and motivating health care employees: integrating Maslow's hierarchy of needs, training and technology," Journal of Nursing Management, vol. 11, no. 5, pp. 315-320, 2003. 


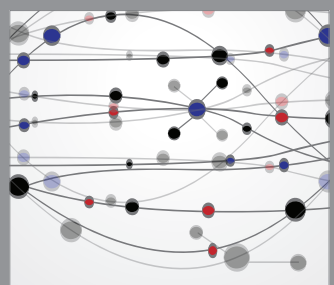

The Scientific World Journal
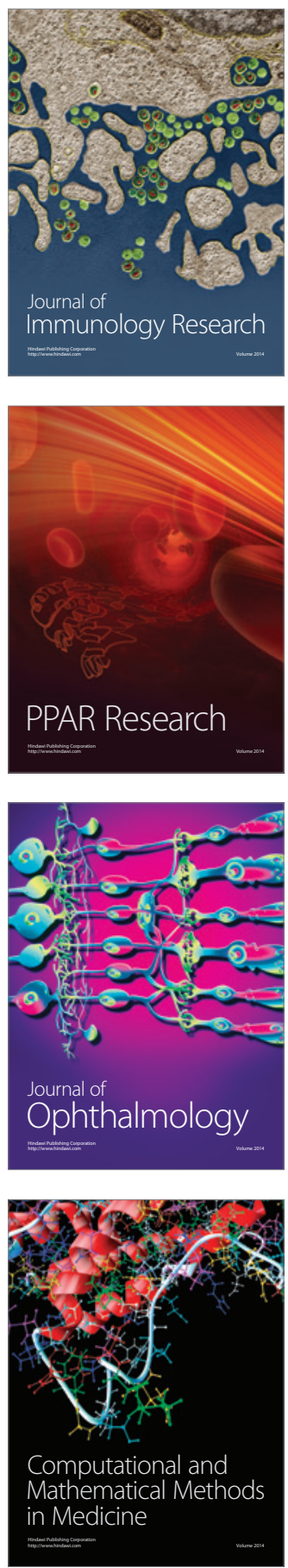

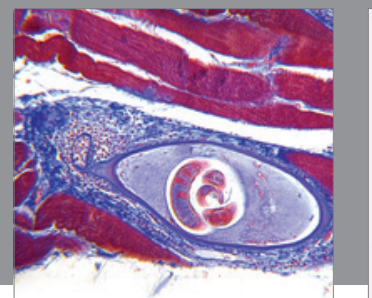

Gastroenterology

Research and Practice
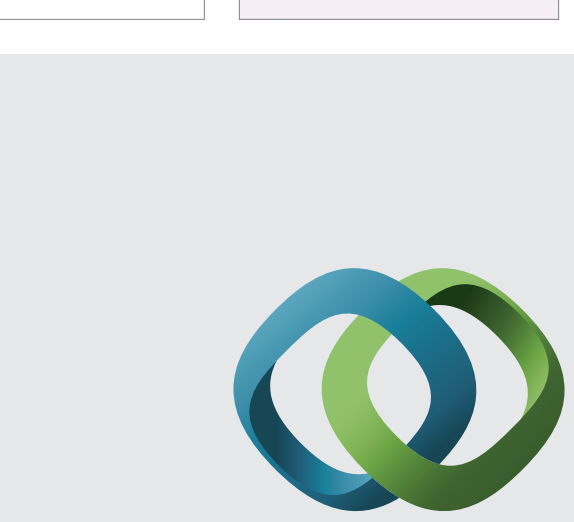

\section{Hindawi}

Submit your manuscripts at

http://www.hindawi.com
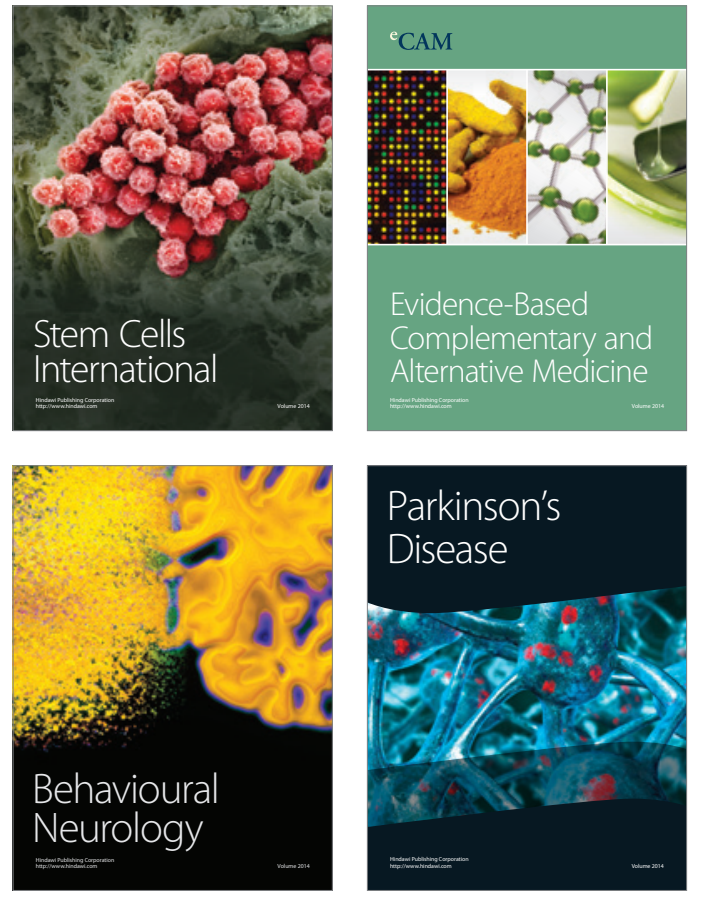
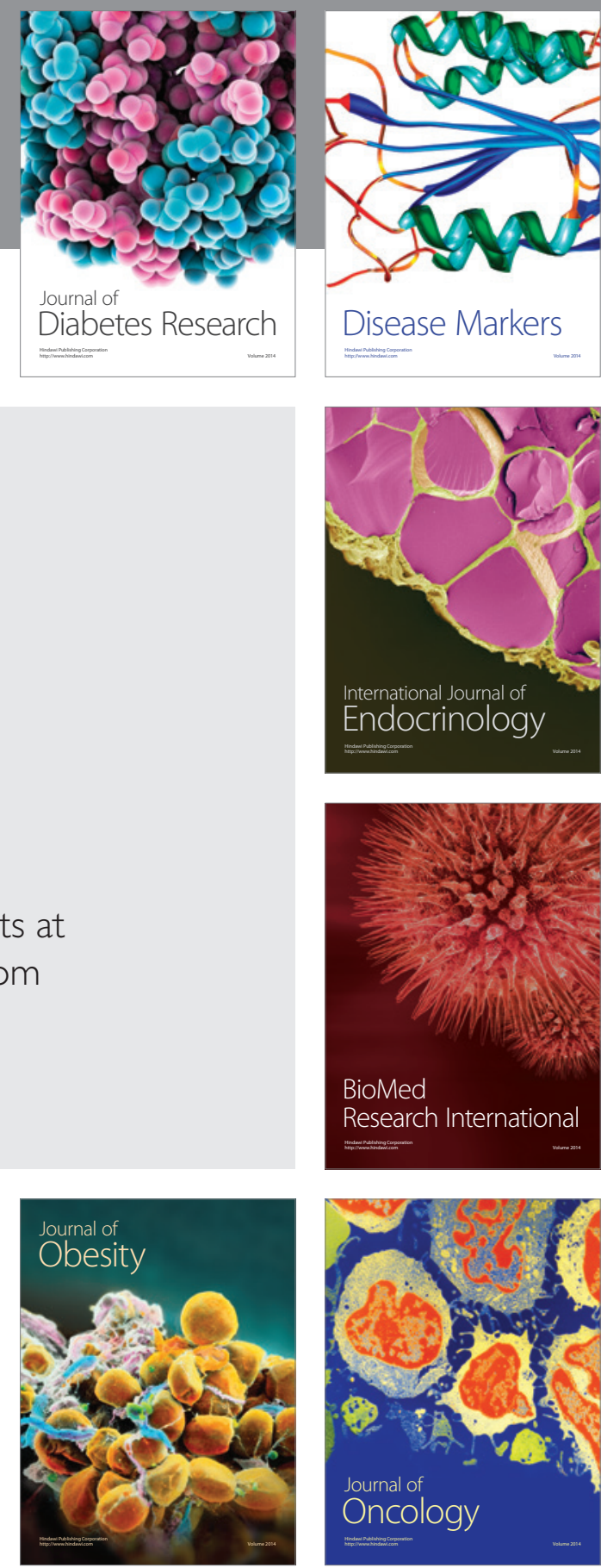

Disease Markers
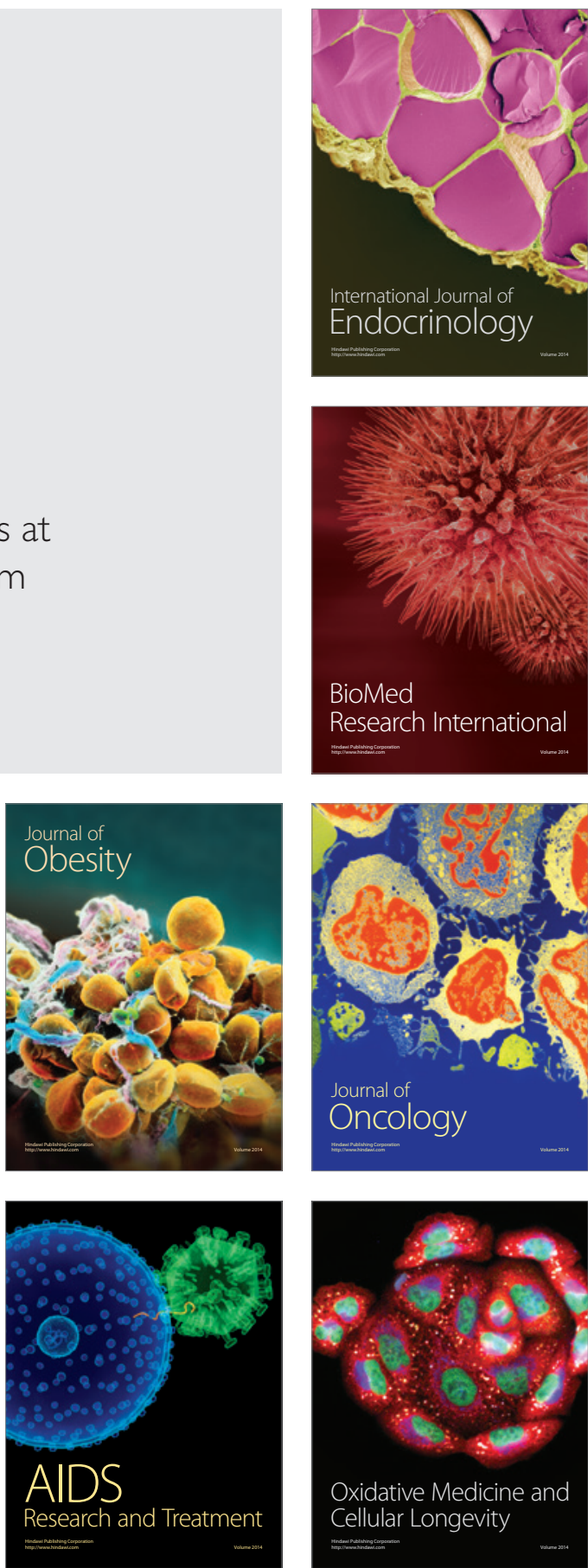